\title{
СЛАВНИЙ ЮВІЛЕЙ ПРОФЕСОРА НАТАЛІ АВРУМІВНИ ВАСИЛЬЕВОї
}

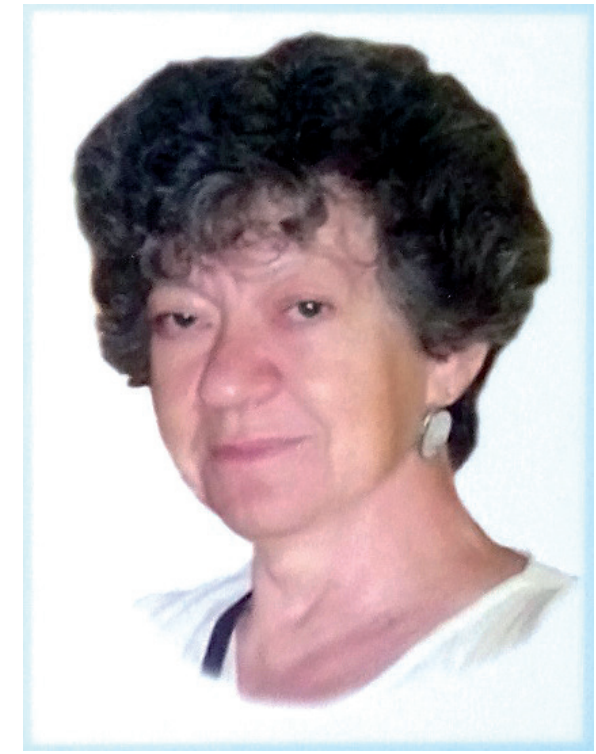

Наведено коротку біографрічну інфрормацію про знаного українського вченого-інфрекціоніста, досвідченого лікаря-клініциста, профресора кафеери інфрекційних хвороб з епідеміологією, шкірними і венеричними хворобами Тернопільського державного медичного університету ім. І.Я. Горбачевського, багаторічного невтомного працівника, члена редакційної колегії Всеукраїнського науковопрактичного медичного журналу «Інфекційні хвороби» Наталю Аврумівну Васильєву.

У травні цього року відсвяткувала ювілей відома вченаінфекціоніст, педагог, профресор кафедри інфекційних хвороб з епідеміологією Тернопільського державного медичного університету ім. І.Я. Горбачевського, доктор медичних наук Наталя Аврумівна Васильєва.

Наталя Аврумівна народилася в м. Єлань Волгоградської області Російської Федерації у 1942 р. Дитинство провела в Туркменії. Після закінчення з відзнакою Ленінградського педіатричного медичного інституту Н.А. Васильєва три роки працювала завідуючою дитячим та інфекційним відділеннями Нестерівської ЦРЛ Калінінградської області, а далі - у 1968-1970 рр. - навчалася в клінічній ординатурі в Ленінградському науково-дослідному інституті дитячих інфекцій, де розпочала свою наукову діяль- ність. У 1971 р. захистила кандидатську дисертацію на тему: «К вопросу о диагностической ценности энзимов с разной внутриклеточной локализацией при инфекционном гепатите у детей (в остром периоде, при хроническом течении и диспансерном наблюдении)» (наукові керівники проф. І.В. Гользанд та І.О. Дашкевич).

Протягом 1970-1972 рр. працювала лікарем-педіатром в системі медичної служби Південної залізниці (Харків) у дитячій залізничній лікарні, а згодом - у дитячому відділенні Основ'янської лікарні.

Подальша трудова і наукова діяльність Н.А. Васильєвої пов'язана з Тернопіллям. 31972 р. вона працювала асистентом на кафедрі інфекційних хвороб та епідеміології Тернопільського медичного інституту, з 2002 р. - доцентом, з 2005 р. - професором кафедри. У 2002 р. Наталя Аврумівна захистила докторську дисертацію «Клініко-патогенетична і епідеміологічна характеристика тяжких форм лептоспірозу та удосконалення лікування» (науковий консультант профр. М.А. Андрейчин).

Широка палітра наукових інтересів Н.А. Васильєвої. Вагомий внесок нею зроблено у вивчення нез'ясованих ланок патогенезу лептоспірозу, підвищення ефективності лікування хворих на цю недугу за рахунок застосування специфічного гомологічного імуноглобуліну, у розробці якого вона брала безпосередню участь. Важливим напрямком наукової діяльності Н.А. Васильєвої є удосконалення діагностики TORCH-інфекцій у вагітних і тактики їх ведення. Цінні дослідження проведені Наталею Аврумівною і стосовно діагностики й лікування хворих на лямбліоз, оперізувальний герпес, ехінококоз, єрсиніози, гострі респіраторні вірусні інфекції та грип.

Наукові здобутки Н.А. Васильєвої широко висвітлені у наукових публікаціях. Вона $€$ автором і співавтором 370 наукових і навчально-методичних праць, у тому числі 7 в іноземних виданнях, 15 винаходів, посібників «Інфекційні хвороби у загальній практиці та сімейній медицині» (1992, 1996, 2007), «Довідника фельдшера» (1997), навчального посібника «Медицина дитинства» (1999), підручника «Фармакотерапія» (2010), монограсрії «Перинатальні інфекції» (2011), «Профресійні інфекційні хвороби» (2014), «Лептоспіроз» (2016). Ювілярка є членом редколегії науково-практичного медичного журналу «Інфрекційні хвороби», у редагуванні якого бере найактивнішу участь; збірників науково- 
практичних конференцій і з'їздів Асоціації інфекціоністів України, а також членом спеціалізованої вченої ради із захисту кандидатських і докторських дисертацій у ДВНЗ «Тернопільський державний медичний університет імені І.Я. Горбачевського».

Н.А. Васильєва - досвідчений педагог, яка багато років навчає і передає свій багатий досвід студентам медичного, фармацевтичного, стоматологічного фракультетів, а також інтернам і курсантам ФПО, чуйний наставник і вихователь молодої зміни. Багато років Н.А. Васильєва плідно керує роботою студентського наукового гуртка. Під її керівництвом захищено кандидатську дисертацію «Соцекосистемний аналіз захворюваності на лептоспіроз у Тернопільській області та удосконалення системи санітарно-епідеміологічного моніторингу».

Н.А. Васильєва - не лише видатний науковець і педагог, але й досвідчений лікар-клініцист, має вищу категорію за фрахом «інфекційні хвороби» (1989 р.). Багато років плідно працює обласний протитоксоплазмозний центр (зараз - центр TORCH-інфекцій), який вона очолює. Клінічні обходи ювілярки приносять користь не тільки пацієнтам, але $є$ й доброю школою як для молодих, так і досвідчених лікарів. Вона брала активну участь у боротьбі з інфекційними хворобами у Таджикистані (1987), у ліквідації спалаху холери в Миколаївській області (1994). Н.А. Васильєва володіє широкою ерудицією та творчою ініціативою, добре розуміє завдання сучасної медицини, віддає багато зусиль для її прогресу, впровадження у практику нових методів діагностики інсекційних хвороб і лікування хворих, $€$ консультантом територіального центру екстреної медичної допомоги. За видатні заслуги у боротьбі з інфекційними хворобами Н.А. Васильєва нагороджена пам'ятною медаллю Агапіта Печерського «За внесок у боротьбу з інфекцій- ними хворобами» (2015), медаллю «Ветеран праці», грамотами Асоціації інсекціоністів України (2010), УОЗ Тернопільської облдержадміністрації (2009) та відділу охорони здоров ` і медичного забезпечення Тернопільської міської ради (2016).

Завдяки високому професійному рівню, людяності й доброзичливості у стосунках, життєрадісності та оптимізму, великій душевній красі Н.А. Васильєва користується заслуженою шаною серед численних друзів, колег та учнів.

У день славного ювілею щиро бажаємо ювілярці міцного здоров'я, творчої наснаги, невичерпної енергії, нових здобутків.

\section{Президія ГО «Всеукраїнська Асоціація} інфрекціоністів України», колектив кафредри інфекційних хвороб з епідеміологією, икірними та венеричними хворобами ДВНЗ «Тернопільський державний медичний університет імені І.Я. Горбачевського», редакція журналу «Інфекційні хвороби».

\section{TO THE ANNIVERSARY OF PROFESSOR NATALIA AVRUMIVNA VASYLIEVA}

SUMMARY. Short biographic information is exposed about the known Ukrainian scientist-infectiologist, experienced doctor-clinician, Professor of the Department of Infectious Diseases with Epidemiology, Skin and Venereal IIInesses of I. Horbachevsky Ternopil State Medical University, long-term tireless worker, member of editorial college of the All Ukrainian research and practice medical journal Infectious Diseases Natalia Avrumivna Vasylieva.

Отримано 12.06.2017 р. 